\title{
Research on the Construction and Maintenance of Rural E-commerce System
}

\author{
Yang Gui \\ Lianning Jianzhu Vocational College; Liaoyang, 111000, China
}

Keywords: rural; e-commerce; status quo; problem; countermeasure

Abstract: In recent years, informatization has become an important driving force for national economic and social development. At the same time, the development of rural e-commerce has also advanced by leaps and bounds. The party and the state have attached great importance to the development of e-commerce for agricultural products and introduced many policies to support the development of e-commerce. This paper starts from the original and development of rural e-commerce, and studies the development status of rural e-commerce in China and the problems existing today, and puts forward some countermeasures and suggestions for the problem.

\section{Introduction}

Fundamentally, the application of e-commerce in rural development not only enhances the benefits of farmers, but more importantly, the three-agricultural e-commerce will promote the process of agriculture and rural modernization, thereby reducing the gap between urban and rural areas and enhancing social stability. There are many advantages in rural e-commerce, but we also notice that there are certain problems in the development of rural e-commerce, which is the starting point of this paper.

\section{Overview of rural e-commerce}

\subsection{Rural e-commerce definition}

The rural e-commerce platform cooperates with intensive rural chain outlets to build a compact and orderly commercial complex and reduce rural commerce through digital and informational means, through intensive management, market-oriented operation, and cross-regional and cross-industry integration. Costs, expansion of rural commercial areas, and making farmers the biggest profit-seekers of the platform, enable businesses to achieve new profit growth.

\subsection{The main content of rural e-commerce}

Rural e-commerce services include online farmer's market, digital farmhouse music, special tourism, featured economy and investment attraction.

In this regard, the online farmer's market quickly transmits information on supply and demand of agriculture, forestry, fishery and animal husbandry, helping foreign businessmen to enter the local 
market and local farmers to open up the domestic market and enter the international market. Carry out agricultural product market and dynamic express delivery, business opportunity matching, product information release, etc.; special tourism relies on local tourism resources to promote external visibility and influence through publicity and promotion.

\subsection{New requirements for the era of rural e-commerce}

On October 14, 2015, the State Council executive meeting held that through mass entrepreneurship and innovation, we should play the role of market mechanism, accelerate the development of rural e-commerce, and organically combine physical stores with e-commerce to create a superposition effect between the real economy and the Internet. Consumption, expansion of domestic demand, promotes agricultural upgrading, rural development, and farmers' income.

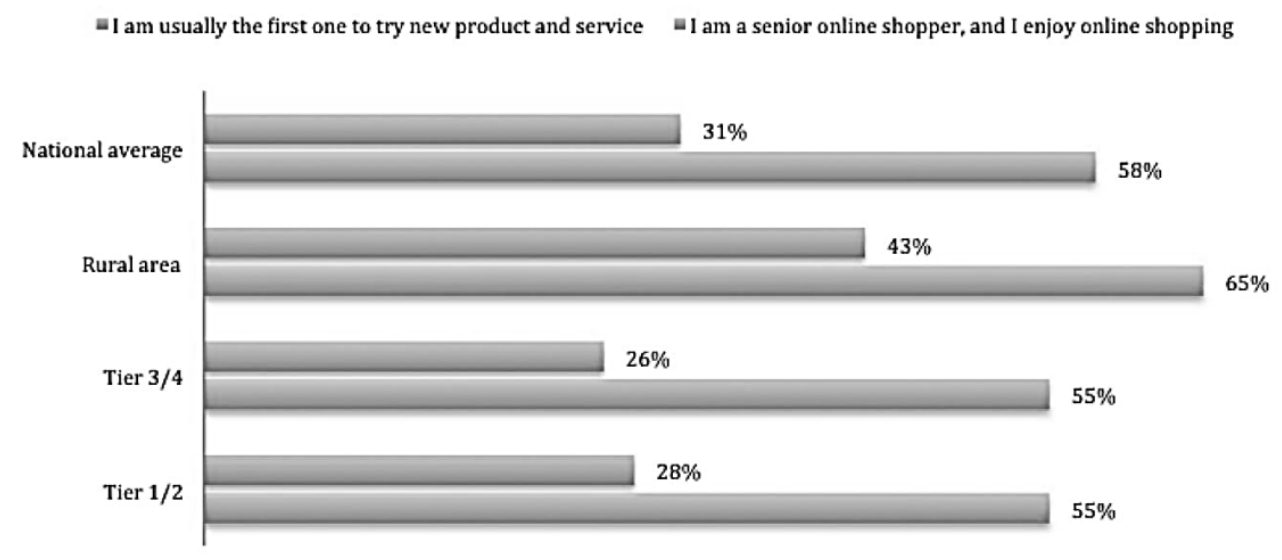

Fig.1 Statistics on Internet consumption of Chinese residents

\section{Status quo of rural e-commerce development in China}

\subsection{The number of rural netizens continues to grow, and the Internet penetration rate continues to rise.}

Since 2015, the development of e-commerce has become an important decision and measure of the Chinese government. The "Opinions on Promoting E-Commerce to Accelerate the Cultivation of New Economic Dynamics" announced on May 7th emphasizes the importance of actively developing rural e-commerce. According to the latest China Internet Network Information Center, as of December 2014, the number of Internet users in rural areas in China has reached 178 million.

Tab.2 China's online consumption and e-commerce development statistics

\begin{tabular}{|lccc|}
\hline & online shopper & non-online shopper & internet coverage \\
\hline Tier $1 / 2$ & $72 \%$ & $28 \%$ & $76 \%$ \\
\hline Tier 3/4 & $66 \%$ & $34 \%$ & $47 \%$ \\
\hline Rural area & $64 \%$ & $36 \%$ & $19 \%$ \\
\hline $\begin{array}{l}\text { National } \\
\text { average }\end{array}$ & $67 \%$ & $33 \%$ & $55 \%$ \\
\hline
\end{tabular}

Among the total number of Internet users, the proportion of rural netizens is $27.5 \%$, an increase of 1.88 million compared with the end of 2013. People; urban netizens increased significantly, compared with 29.29 million at the end of 2013. The Internet penetration rate of rural residents in 
China is $28.8 \%$, which is $0.7 \%$ higher than that in 2013 , while that of urban residents is $62.8 \%$, an increase of $2.5 \%$ compared with 2013.

\subsection{The number of e-commerce platforms related to agriculture has soared, and rural e-commerce has flourished.}

According to data from the Department of Commerce of the Ministry of Commerce of the Ministry of Commerce and Information Technology, China has opened more than 30,000 agricultural e-commerce platforms to date, including 3,000 e-commerce platforms for agricultural products. Nowadays, it is the most popular Taobao online. There are also about 400,000 online stores operating agricultural products. In Hebei, Zhejiang, Jiangsu, Shandong and other places, there are 212 different types of Taobao villages, which have opened up channels for the sales of agricultural products.

\section{Problems in the development of rural e-commerce}

\subsection{Farmers have a small number of Internet users and lack of knowledge about e-commerce}

From the national situation, the penetration rate of farmers online is still very low. According to the latest survey data of the 31 provinces, municipalities and autonomous regions of the Ministry of Agriculture, the average proportion of farmers online in the country is only $0.2 \%$. Conduct a consistency check on it to obtain:

$$
\mathrm{CR}=0.0269<0.1
$$

And the proportion of netizens engaged in agriculture-related occupations is less than $1 \%$, and mainly concentrated in the eastern region; the local farmers' Internet access rate is almost zero.

\subsection{Lack of rural e-commerce application talents}

The talent issue is a fundamental problem that restricts the development of rural e-commerce. Farmers have low cultural quality, are slow to respond to new technologies and new information, and have insufficient confidence in e-commerce. Talents who understand e-commerce technology are seldom willing to serve in rural areas, which make the rural e-commerce application talents seriously lacking.

\subsection{Rural e-commerce infrastructure is weak}

Complete and efficient communication facilities are the prerequisite for the rapid development of e-commerce. However, the network facilities at the county level in China are still weak, and the rural information service stations are not sound enough, which has long restricted the improvement of rural production efficiency. In addition, China's rural network construction also shows obvious regional characteristics, the eastern coastal economic level is relatively high, the network infrastructure is relatively fast, and the rural network facilities in the central and western regions are relatively backward.

\section{Countermeasures and recommendations}

\subsection{Strengthening the education and training of rural residents' e-commerce}

It is necessary to strengthen rural education, arrange professional and technical personnel to 
conduct on-the-spot training, enable more people to know computers and network, and teach farmers how to use e-commerce platform, that is, how to search for information online, how to conduct transactions online, and how to Online settlement makes the farmers' production scientific and large-scale. In the work of developing rural e-commerce, it is necessary to widely publicize the superiority of e-commerce.

\subsection{Strengthening the construction of rural e-commerce infrastructure}

The expansion of the e-commerce platform requires the support of complete network facilities and high network penetration rate. Therefore, we must do a good job in the planning and construction of rural network infrastructure, increase the penetration rate of telephone and cable TV, increase the level of adequate broadband services, reduce costs, reduce costs, and create favorable conditions for the development of e-commerce.

\subsection{Establish and improve the agricultural product logistics distribution system}

There are many kinds of agricultural products in China, the production units are small, the degree of organization of production is low, the distribution demand is more than one point, and the logistics technology is more difficult. Therefore, it is necessary to seriously study the distribution of agricultural products, use advanced information technology and network technology to transform the traditional agricultural product circulation model, build a modern logistics distribution system, optimize the circulation mechanism and process, optimize resource allocation, reduce circulation costs, and improve production and operation efficiency. And vigorously develop third-party logistics, so that agricultural products can be circulated quickly and at low cost.

\section{Summary}

In summary, e-commerce can help people engaged in agricultural production to obtain valuable rural information and business information very conveniently and quickly. Because of the direct sales model of agricultural enterprises, it has the characteristics of openness, low cost and high efficiency. It is a new sales model for agricultural enterprises. By conducting online direct sales, we can effectively control inventory, compress circulation, and control distribution costs. In this way, rural e-commerce can promote the production of agricultural modernization, ensure the smooth flow of rural information, and greatly serve rural enterprises and agricultural producers, promote the rapid development of agricultural industrialization, and truly realize the modern production management of rural industries.

\section{References}

[1] Paul D L. Collaborative Activities in Virtual Settings: A Knowledge Management Perspective of Telemedicine[J]. Journal of Management Information Systems, 2006, 22(4):143-176..

[2] Amutabi M N. Prospects and Dilemmas of Information and Communication Technology (ICT) in University Education in Africa: The Case of Kenya.[J]. 2004.

[3] Mason L. A Marshallese Nation Emerges from the Political Fragmentation of American Micronesia[J]. Pacific Studies, 2009, 13. 